\title{
IN SILICO ANALYSIS OF THE Dof TRANSCRIPTION FACTOR FAMILY IN Coffea canephora
}

\author{
Vinícius Garcia ${ }^{1}$, Alessandra Ferreira Ribas ${ }^{2}$, Luiz Gonzaga Esteves Vieira², Tiago Benedito dos Santos ${ }^{1,2}$ \\ ${ }^{1}$ Universidade do Oeste Paulista - UNOESTE, Especialização Lato Senso em Biotecnologia, Presidente Prudente, SP. \\ ${ }^{2}$ Universidade do Oeste Paulista - UNOESTE, Programa de Pós-Graduação em Agronomia, Presidente Prudente, SP. E- \\ mail: dossantos@unoeste.com
}

\begin{abstract}
The Dof family (DNA-binding with One Finger) is a group of transcription factors that are involved in a variety of functions of importance for different biological processes in plants, such as plant growth, development and response to biotic and abiotic stresses. The Dof genes have been identified and characterized in many plant species, but so far there is no information about these genes in coffee species. In the present study, we identified 24 Dof members in Coffea canephora using the Coffee Genome Hub database. Systematic bioinformatics analyses were performed to characterize all CcDof genes, including complete genome sequence, conserved protein domains, subcellular locations, phylogenetic relationships and gene expression profiles in different tissues. The results obtained here provide new insights into the CcDof gene family, allowing the design of future experiments for the molecular characterization of these genes in coffee plants.
\end{abstract}

Key words: Bioinformatics; C. canephora; Dof; transcription factor.

\section{ANÁLISE IN SILICO DE FATORES DE TRANCRIÇÃO DA FAMÍLIA Dof EM Coffea canephora}

\section{RESUMO}

A família Dof (DNA-binding with One Finger) é um grupo de fatores de transcrição que desempenham papéis importantes no crescimento, desenvolvimento e na resposta das plantas aos estresses bióticos e abióticos. Os genes Dof foram identificados e caracterizados em várias espécies de plantas; entretanto até o presente momento não há informações sobre esses genes em café. No presente estudo foram identificados 24 membros da família Dof no genoma de C. canephora depositados no banco de dados Coffee Genome Hub. Análises sistemáticas de bioinformática foram realizadas para caracterizar os genes Dof em C. canephora, incluindo a análise de sequências genômicas, domínios proteicos conservados, localizações subcelulares, relações filogenéticas e perfis de expressão gênica em diferentes tecidos. Os resultados obtidos fornecem uma melhor compreensão sobre a família dos genes CcDof permitindo projetar experimentos futuros para caracterização molecular desses genes no cafeeiro.

Palavras-chave: Bioinformática; C. canephora; Dof; fator de transcrição.

\section{INTRODUCTION}

The Dof proteins are a family of plant-specific transcription factors (TFs) that play a variety of biological processes, such as biotic and abiotic stresses, seed germination, photosynthesis, secondary metabolic regulation, growth and development (GUPTA et al., 2015; YANG et al., 2018). The conserved Dof domain is formed by 52 amino acid residues is located at the $\mathrm{N}$-terminal region and characterized by the presence of four cysteine residues (C: $\mathrm{CX}_{2} \mathrm{CX}_{21} \mathrm{CX}_{2} \mathrm{C}$ ) which bind covalently to a zinc atom $\left(\mathrm{Zn}^{2+}\right)$ forming a finger-like structure (DNA binding with One Finger) (Figure 1). 
Figure 1. Representation of the Dof domain based on the amino acid sequences of Eleusine coracana. Figure adapted and reviewed by Gupta et al. (2015).

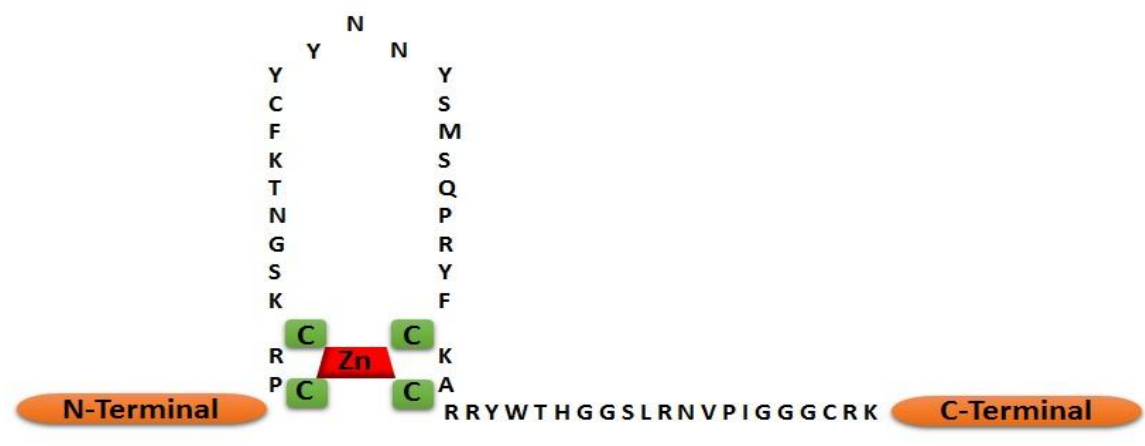

The Dof TF proteins, in addition to the DNA-binding domain, also contain a bipartite nuclear localization signal (NLS) that overlaps the conserved Dof DNA-binding domain (KREBS et al., 2010). The first report on the identification and characterization of the Dof gene was in Zea mays (YANAGISAWA; SHEEN, 1998).

Based on bioinformatics analysis generated by the large-scale sequencing genome projects, numerous studies were able to identify families of genes encoding the Dof transcription factors in different plant species: Ricinus communis (JIN; LIU, 2014), Chinese cabbage (MA et al., 2015), Cajanus cajan (MALVIYA et al., 2015), Medicago truncatula (SHU et al., 2015), Sorghum bicolor (GUPTA et al., 2016), Capsicum annuum (WU et al., 2016), Phaseolus vulgaris (ITO et al., 2017), Setaria italica (ZHANG et al., 2017a), Prunus persica (CHEN et al., 2017), Jatropha curcas (WANG et al., 2018), Ananas comosus (AZAM et al., 2018), E. coracana (GUPTA et al., 2018) and Gossypium hirsutum (LI et al., 2018). In this sense, the scope of this study was to identify and characterize the $C$. canephora Dof family based on information available at the Coffee Genome Hub, an integrated web-based database resource developed by IRD and Cirad (http://coffee-genome.org/). This study provides valuable information about candidate genes for future functional analysis for understanding the potential mechanisms of CcDof genes in this important coffee species.

\section{MATERIAL AND METHODS}

\section{Identification and characterization of the Dof} genes in $C$. canephora

From searches in the $C$. canephora database available at the Coffee Genome Hub website (http://coffee-genome.org/; DENOUED et al., 2014) were found 24 sequences referring to the keyword Dof. In order to verify if the identified sequences showed similarity with Dof genes of other organisms, each putative CcDof gene had its sequence individually confronted with the sequences deposited in the NCBI database (BlastX and BlastP; ALTSHUL et al., 1997). Additionally, the physico-chemical characteristics of Dof proteins, such as molecular weight $(\mathrm{Mw})$ and isoelectric point ( $\mathrm{pl})$, were calculated using the ExPASy - Compute $\mathrm{pl} / \mathrm{Mw}$ tool (https://web.expasy.org/compute_pi/). In silico analysis for the subcellular location, the Plant-mPLoc

(http://www.csbio.sjtu.edu.cn/bioinf/plantmulti/; CHOU; SHEN, 2010) algorithms with default parameters were used. In addition, the hydrophilic/hydrophobic property index of all Dof protein sequences was performed through the GRAVY calculator program.

\section{Chromosomal location and exon/intron structure of $C c D o f$ genes \\ All CcDof genes identified in the $C$.} canephora genome were physically mapped in the chromosomes through the MapChart software (VORORIPS, 2002), according to their genome coordinates. The exon/intron structures of CcDof genes were generated by Gene Structure Display Server software (GSDS; http://gsds.cbi.pku.edu.cn/; HU et al., 2015) through a comparison of the predicted coding sequence (CDS) with their corresponding genomic DNA sequences (DENOUED et al., 2014).

Sequence alignment, phylogenetic analysis and classification of CcDof genes

Multiple sequence alignment of the identified CcDof protein sequences was performed using the CLC Main Workbench 8.0 program through the tool ClustalW, in order to identify the regions containing the characteristic domain of the Dof family (Figure 4). Next, 
phylogenetic trees were generated with MEGA 7 software by using the Neighbor-Joining method, p-distance substitution model, pairwise deletion analysis. The reliability of the trees was assessed by the bootstrap method and branches of less than 50\% bootstrap support (1000 replicates) were collapsed.

\section{Conserved motif analysis}

The prediction of the conserved Dof motifs of the putative proteins was performed by using the Multiple EM for Motif Elicitation (MEME;

http://meme.ebi.edu.au/meme/intro.html;

BAILEY et al., 2009), using the same parameters: motif length set to 6 - 100, motif sites set to 2 120 , and maximum number of motifs set to 20 , respectively.

\section{Expression of the Dof gene in different tissues}

The tissue-specific expression patterns of the different members of the Dof gene family in C. canephora was determined by employing the transcriptional profiles obtained by RNA sequencing (RNAseq) from root, stamen, pistil, leaf, perisperm and endosperm libraries (DENOUED et al., 2014). The RPKM (Reads Per Kilobase per Million mapped reads) values of each putative gene from each library were displayed in Heatmap format to infer the transcriptional profiles in the respective tissues of C. canephora plants.

\section{RESULTS AND DISCUSSION}

Dof (DNA-binding with one finger) domain proteins constitutes an important family of TFs that are associated to the regulatory network of various developmenta processes in plants (SILVA et al., 2016; KANG et al., 2016; CORRALES et al., 2017). As has been shown in the literature, the number of Dof genes described and characterized are variable among plant species: S. tuberosum (35), Chrysanthemum morifolium (20), P. vulgaris (36), S. italica (35), A. comosus L. (26), Malus domestica (60), Boehmeria nivea L. Gaud (19) (VENKATESH; PARK, 2015; SONG et al., 2016; ITO et al., 2017, ZHANG et al., 2017a; AZAM et al.; 2018, ZHANG et al., 2017b; XU et al., 2018), respectively. In this study, we were able to identify 24 CcDof genes within the $C$. canephora genome database (DENOUED et al., 2014), which were named (CcDof1 through CcDof24) in descending order according to their position within the $C$. canephora chromossomes (Table 1).

Detailed information on the physicochemical characteristics of CcDof proteins is shown in Table 1 . The deduced size of the amino acid sequences of the CcDof proteins ranged from 167 to 513 aa, the theoretical isoelectric point (pl) from 4.24 to 10.13 and the molecular weight (Mw) of from 14289.36 to $49223.78 \mathrm{Mw}$.

Table 1. List of the CCDof TFs identified in the genome of $C$. canephora and related information on gene name, locus ID, chormossome number, protein length (aa), molecular weight (Mw), isoelectric point (pl), hydropathy (GRAVY), subcellular localization and orthologous in A. thaliana

\begin{tabular}{|c|c|c|c|c|c|c|c|c|}
\hline Gene Dof & Locus ID C. canephora & Chromosome number & Protein length (aa) & Molecular weight (Mw) & Theoretical (pl) & GRAVY & Subcellular localization & Ortholog in Arabidopsis \\
\hline CcDof1 & Cc01_g11670 & chr1:30320517..30322291 & 290 & 24710.20 & 7.00 & -0.670 & Nucleus & AT2G28510.1 \\
\hline CcDof2 2 & Cc01_g12730 & chr1:31245653..31246860 & 307 & 25986.88 & 9.17 & -0.559 & Nucleus & AT3G55370.3 \\
\hline CcDof3 & Cc02_g01210 & chr2:972655..974150 & 311 & 27092.76 & 6.58 & -0.530 & Nucleus & AT4G24060.1 \\
\hline CcDof4 & Cc02_g07960 & chr2:6332990..6334233 & 336 & 29745.12 & 8.71 & -0.530 & Nucleus & АТ3G55370.3 \\
\hline CcDof5 & Cc02_g12890 & chr2:11166886..11167800 & 288 & 24995.71 & 6.63 & -0.501 & Nucleus & AT1G07640.3 \\
\hline CcDof6 & Cc02_g13590 & chr2:11739465..11740752 & 332 & 29214.38 & 9.06 & -0.503 & Nucleus & AT1G28310.2 \\
\hline CcDof7 & Cc02_g14960 & chr2:13101644..13102165 & 174 & 12530.81 & 9.38 & -0.761 & Nucleus & AT1G29160.1 \\
\hline CcDof8 & Cc02_g39630 & chr2:54118424..54119805 & 290 & 24658.45 & 9.57 & -0.520 & Nucleus & АТ3G61850.4 \\
\hline CcDofg & Cc04_g02150 & chr4:1676203..1676925 & 241 & 18330.64 & 6.45 & -0.778 & Nucleus & AT1G51700.1 \\
\hline CcDof 10 & Cc04_g08250 & chr4:6608932..6609990 & 353 & 30627.49 & 5.64 & -0.554 & Nucleus & AT5G60850.1 \\
\hline CcDof 11 & Cc04_g14150 & chr4:20217841..20219685 & 307 & 27326.52 & 6.52 & -0.645 & Nucleus & AT5G62940.1 \\
\hline CcDof12 & Cc04_g16510 & chr4:26823179..26825416 & 502 & 47741.12 & 7.6 & -0.762 & Nucleus & AT3G47500.1 \\
\hline CcDof13 & Cc06_g02740 & chr6:2198639..2199961 & 356 & 31614.37 & 9.39 & -0.462 & Nucleus & AT2G37590.1 \\
\hline CcDof14 & Cc06_g06640 & chr6:5305481..5306557 & 340 & 30396.35 & 5.37 & -0.527 & Nucleus & АT3G52440.1 \\
\hline CcDof15 & Cc07_g03470 & chr7:2412880..2415816 & 513 & 49223.78 & 6.20 & -0.802 & Nucleus & AT5G39660.1 \\
\hline CcDof16 & Cc07_g05550 & chr7:3916861..3917589 & 243 & 18288.37 & 8.04 & 0.010 & Nucleus & AT3G50410.1 \\
\hline CcDof17 & Cc07_g05650 & chr7:3979174..3980220 & 349 & 31143.82 & 9.01 & -0.434 & Nucleus & AT5G60200.1 \\
\hline CcDof18 & Cc07_g13810 & chr7:10399450..10400532 & 361 & 32196.76 & 8.93 & -0.475 & Nucleus & AT5G65590.1 \\
\hline CcDof19 & Cc08_g03320 & chr8:4306033..4308169 & 269 & 24871.87 & 9.85 & -0.606 & Nucleus & AT4G24060.1 \\
\hline CcDof 20 & Cc08_g03360 & chr8:4335942..4338195 & 167 & 13459.31 & 10.13 & -0.905 & Nucleus & AT4G24060.1 \\
\hline CcDof 21 & Cc08_g16560 & chr8:31049028..31050438 & 301 & 25693.09 & 7.17 & -0.604 & Nucleus & AT4G24060.1 \\
\hline CcDof 22 & Cc10_g03720 & chr10:2787475..2788311 & 213 & 14289.36 & 6.45 & -0.507 & Nucleus & AT5G60200.1 \\
\hline CcDof 23 & Cc10_g14200 & chr10:24787234..24788088 & 285 & 24832.08 & 4.24 & -0.511 & Nucleus & AT1G21340.1 \\
\hline CcDof 24 & Cc11_g12870 & chr11:29855782..29858689 & 463 & 43776.71 & 8.61 & -0.730 & Nucleus & AT5G39660.1 \\
\hline
\end{tabular}


The 24 CcDof genes were unevenly distributed in almost all 11 chromosomes of $C$. canephora, with the exception of chromossomes 3, 5 and 9 (Figure 2). Chromosomes 2, the larger C. canephora chromosome (55 Mb), contained the highest number of Dof genes (6) (Figure 2). For comparison's sake, the 34 Dofs genes in $S$. lycopersicum were identified and distributed in
12 chromosomes, with the exception of chromosomes 7 and 12 (CAl et al., 2013), while in A. comosus, Azam et al. (2018) the identified 26 Dofs genes were mapped on all the 25 chromosomes of that species.

Figure 2. Distribution and chromosomal location of the $C c D$ of genes in the $C$. canephora genome.

$\begin{array}{llllllllllll}\text { Chr01 } & \text { Chr } 02 & \text { Chr03 } & \text { Chr04 } & \text { Chr05 } & \text { Chr06 } & \text { Ch07 } & \text { Ch08 } & \text { Chr } 09 & \text { Chr } 10 & \text { Chr } 11\end{array}$

$\left.\right|_{3.2} ^{30.3}=$

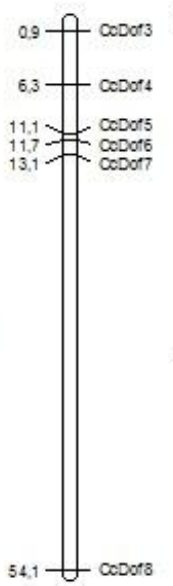

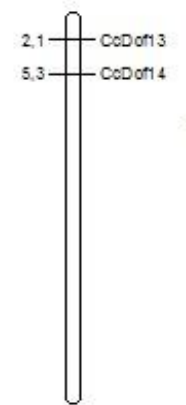

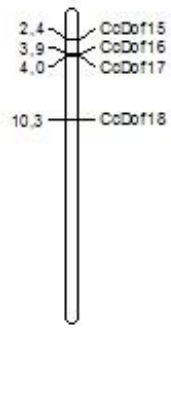

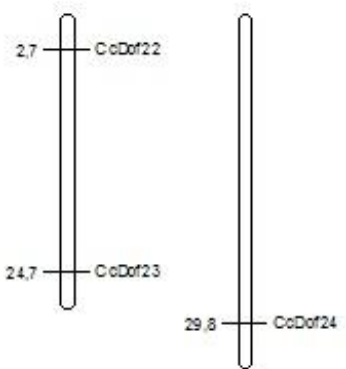

According to Koralewski and Krutovsky (2011), the structural and exon/intron organization can be used for examining the evolutionary relationships among genes or organisms. As commonly reported (KUSHWAHA et al., 2011; CHEN et al., 2017; ZHANG et al., 2017b), the distribution of intron in Dof genes is variable among plant species. In C. canephora, the exon/intron analysis depicted that the number of introns in the open reading frames
(ORFs) varied from 0 to 5 , with CCDof19 presenting a maximum of 5 introns (Figure 3 ). The fact that CCDof genes presents on average less introns than other genes makes them more sensitive to transcriptional regulation, which suggests that they may trigger diverse biological processes in the plant (JIN et al., 2014). 
Figure 3. Gene structure of the 24 CcDof genes in C. canephora genome. Yellow boxes indicate exon (CDS) and lines introns.

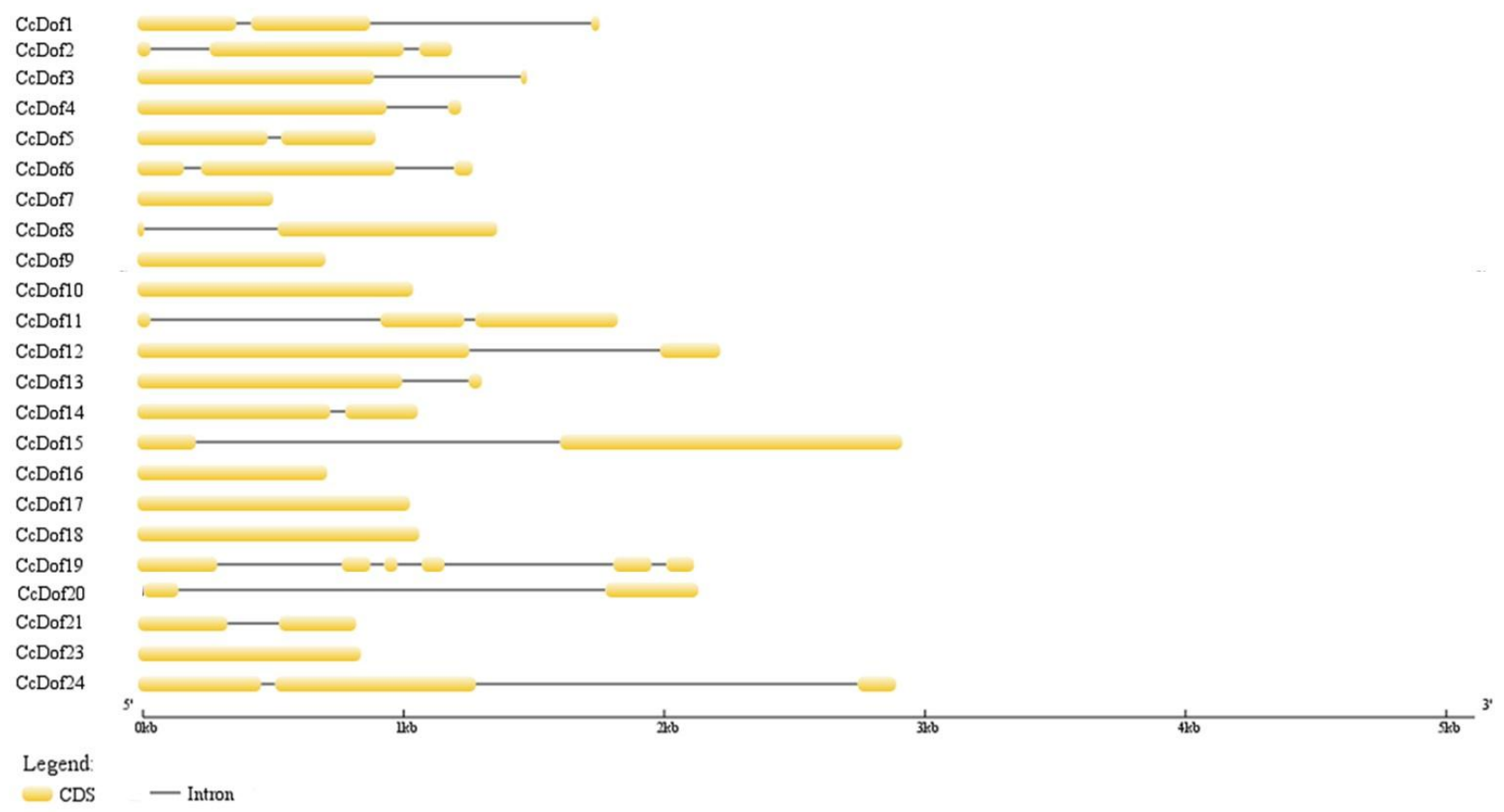

As mentioned earlier, the Dof TF family is characterized by having the conserved $\mathrm{N}$-terminal DNA-binding domain $\left(\mathrm{CX}_{2} \mathrm{CX}_{21} \mathrm{CX}_{2} \mathrm{C}\right)$ (YANAGISAWA, 1995; 1997). The multiple sequence alignment of the CcDof proteins revealed the typical presence of amino acid residues at the the Zinc-finger domain (Figure 4), similarly to that described for other plant species, such as banana (DONG et al., 2016), moso bamboo (WANG et al., 2016) and apple (ZHANG et al., 2017b). 
Figure 4. Multiple alignment of amino acid sequences of the DNA-binding domain of the $C$. canephora Dof transcription factors.

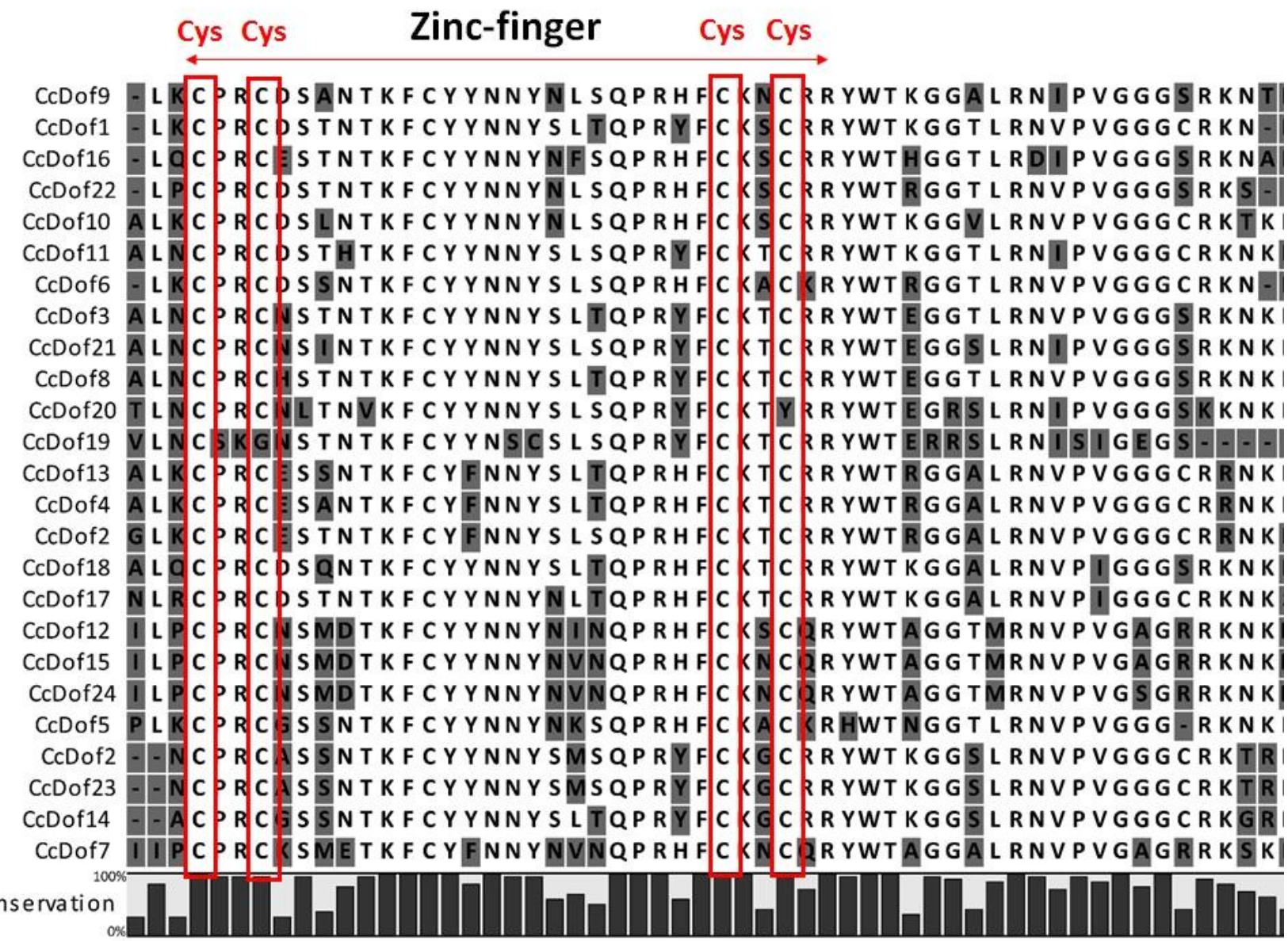

It is well known that classificaton of genes and phylogeny are important to the functional analysis and to understand the evolutionary history of a particular gene family. The phylogenetic tree topology allowed to classify the CcDofs into 6 groups (groups I-VII). Each group was composed of a varied number of Dof genes (2 to 8 members) with a bootstrap value relatively high for each subgroup, indicating the relatedness of the Dof genes within each group (Figure 5). In Ricinus communis Dof FTs were clustered in four groups, which could be divided into seven subgroups (JIN et al., 2014), while Wei et al. (2018) divided the Dof TFs of eggplant in 4 groups and 9 subgroups.

Using bioinformatics tools is possible to identify sequence Motifs, which represent highly conserved regions (functional regions) sharing the same function and, probably, having a common origen (GIBAS et al., 2001). A total of 24 conserved motifs have been identified in the CcDof proteins (Figure 5). The motif 1 (EQALKCPRCDSTNTKFCYYNNYSLQPRHFCKTCRRY WTKGGTLRNVPVGGGSRKNK) was confirmed as the conserved Dof domain in almost all sequences of the CcDof proteins (Figure 5). 
Figure 5. Phylogenetic tree constructed from the alignment of the $24 \mathrm{CcDof}$ proteins. The sequences were aligned using ClustalW at MEGA 7.0 software and the phylogenetic tree was constructed by NeighborJoining method. Different color boxes distinguish the groups. The motif analysis was performed using MEME tool and the motifs are indicated by different-colored boxes.

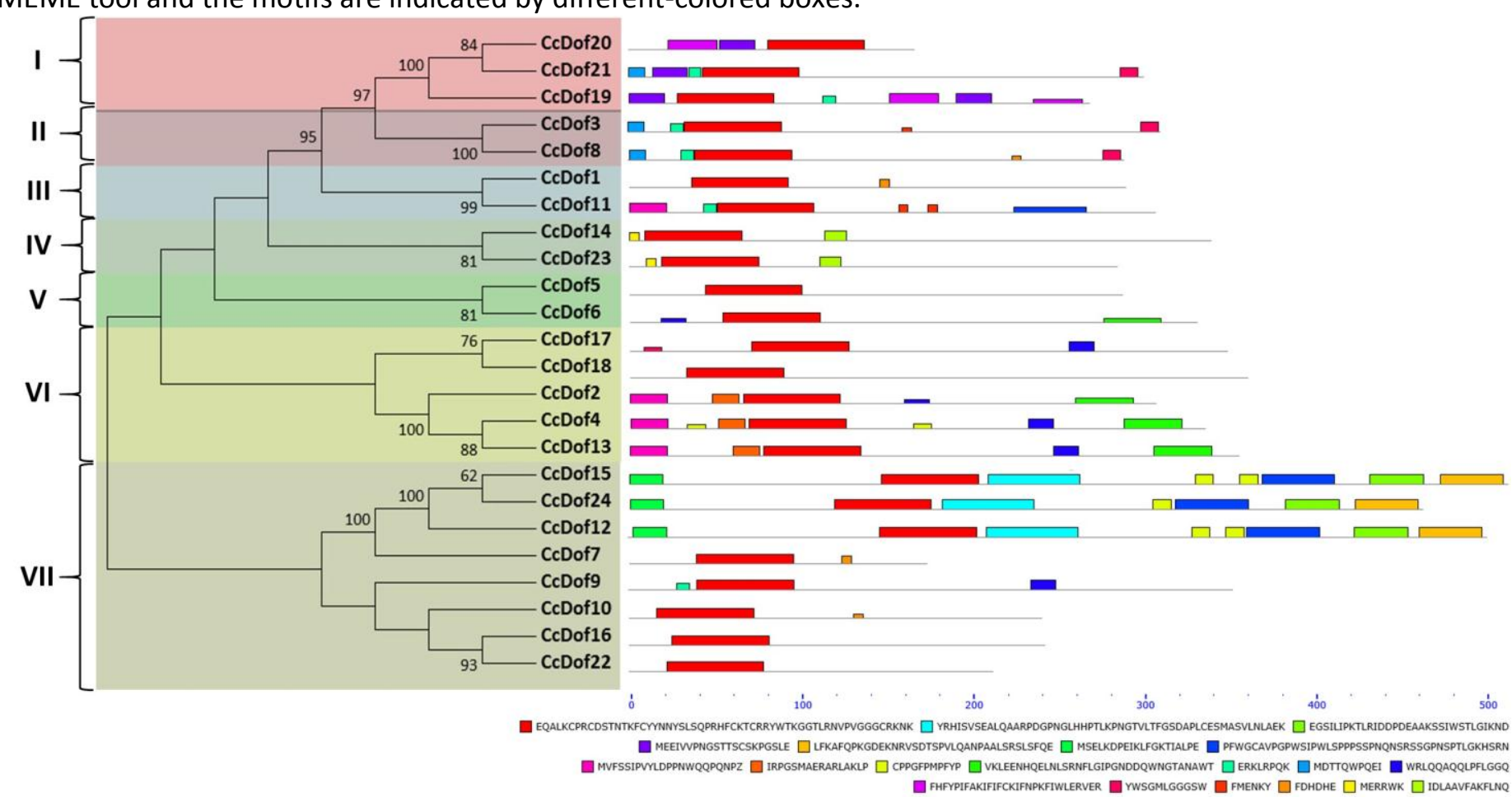

Another phylogenetic tree was constructed including 36 AtDof sequences from Arabidopsis aiming at clustering the CcDofs according the classification proposed by Lijavetzky et al. (2003) (Figure 6), where Dof proteins were grouped into four major clusters ( $A, B, C$ and $D)$ and eight subclusters designated as B1, B2, C1, C2.1, C2.2, C3, D1 and D2. 
Figure 6. Phylogenetic tree of Dof proteins from C. canephora and A. thaliana. The 24 C. canephora and 36 A. thaliana protein sequences were aligned using ClustalW at MEGA 7.0 software and the phylogenetic tree was constructed by Neighbor-Joining method.

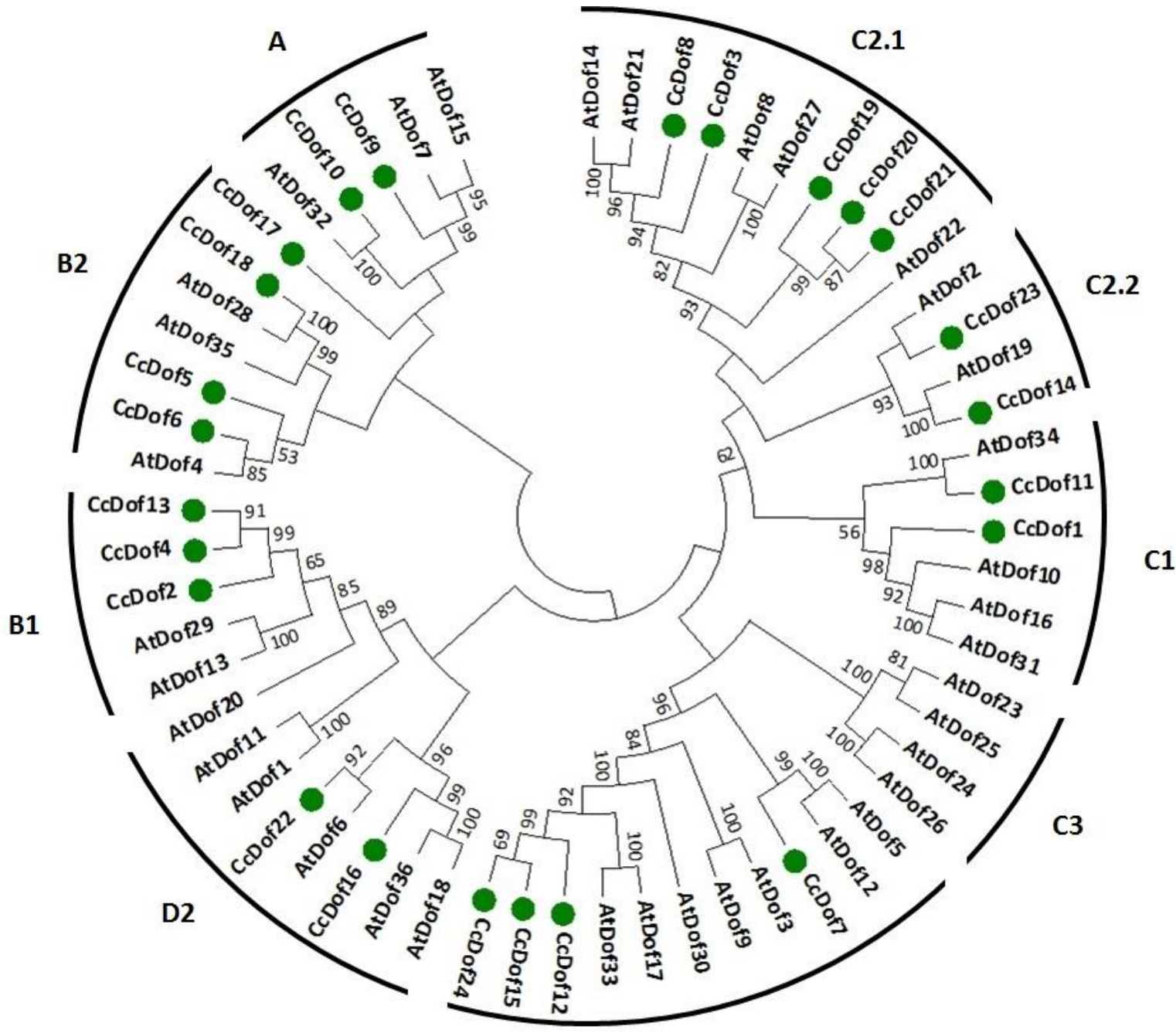

D1

The groups $B$ and $C$ had the largest number of CcDofs, with 7 and 9 genes respectively, while group $A$ represents the smallest clade with only 2 members (CcDof9 and 10) (Figure 6). The subgroup $C 3$, which was originally identified in Arabidopsis (AtDofs 22, 23, 24, 25 and 26), do not possess any CcDof (Figure 6). Our results corroborate with earlier studies studies that demonstrated that this subgroup is found only in a few species, such as in cruciferous plants, with no apparent homologues observed in important crops as rice, tomato, chinese cabbage and banana (LIJAVETZKY; CARBONERO; VICENTECARBAJOSA; 2003; CAl et al., 2013; MA et al., 2015; FENG et al., 2016).
Recently, Denoued et al. (2014) provided the complete sequence of the genome of $C$. canephora, a perennial diploid species $(2 n=2 x=$ 22 chromosomes), also known as Robusta. In the scope of that same project, the RNA-seq data of various coffee cDNA libraries (roots, stamen, pistil, leaves, perisperm and endosperm) were made available at the Coffee Genome Hub platform (http://coffee-genome.org/). Using the RPKM data, we investigated the expression patterns of the 24 CcDof genes in those different tissues of $C$. canephora (Figure 7). 
Figure 7. In silico expression profile of the $C c D o f$ genes of $C$. canephora. Heat map showing the expression pattern of 24 genes in different tissues. The expression of the genes is represented in the heat map in the colour scale of 0-272 in green-red colour scheme. The genes are represented in columns while tissues are shown in rows.

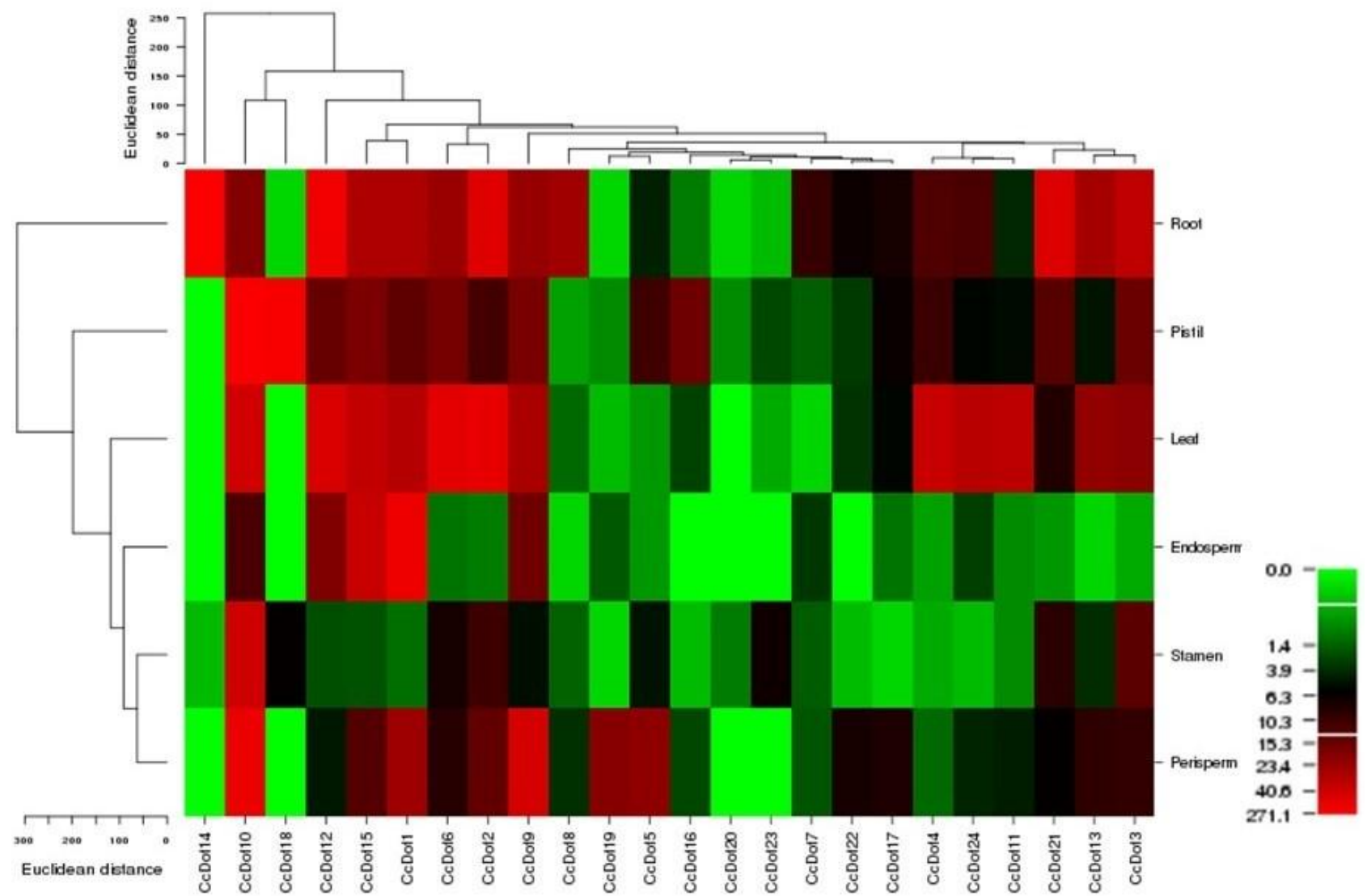

The heat map generated for in silico expression profiling showed differential transcript abundance of the $C c D$ of genes in all libraries (Figure 7). For example, were able to identify 14 CcDof genes (CcDof1, 2, 3, 4, 6, 8, 9, $10,12,13,14,15,21$ and 24) abundantly expressed in roots. A large number of $C c D o f$ genes were also expressed in leaf tissues (CCDof1, $2,3,4,6,9,10,11,12,13,15$ and 24). Similarly to our findings, $X u$ et al. (2018), analyzing the expression patterns of Dof genes in Boehmeria nivea, observed that many of these genes were highly expressed in roots and leaves. In potato, an expressive number of StDof genes (StDof15a, StDof22, StDof24, StDof26, StDof29a, StDof32 and StDof34) showed maximum expression levels in the leaf tissues (VENKATESH; PARK, 2015). Also, specific expression of Dof genes in root, leaf and petiole tissues of Daucus carota was observed by Huang et al. (2016).

On the other hand, only 6 (CCDof1, 2, 5, 9, 10 and 19) and 3 (CCDof1, 12 and 15) CcDofs were highly expressed in the perisperm and in the endosperm, respectively. Particularly regarding the reproductive organs, the Dof family genes were more highly expressed in the pistils, as the cDNA library from stamen tissues showed lower number of transcripts of the majority of the identified CcDof genes (Figure 7). It is also worth mentioning that some CcDof genes (e.g. CcDof1, $2,10,12$ and 15) were ubiquitously expressed in the various coffee tissues. Finally, here we have also shown that the CCDof genes under investigations clustered together based on their expression in different tissues, which clearly indicates that they are involved in diverse physiological functions in C. canephora.

\section{CONCLUSIONS}

This study is the first to present data on in silico identification and analysis of $C$. canephora Dof family genes. A total of 24 CcDof members have been identified and were classified into seven phylogenetically related groups. Also, we conducted a detailed analysis regarding their gene structures, protein motifs and chromosome distribution. A heat map analysis of the $C c D$ of genes revealed that they are primarily expressed in root and leaf tissues. Finally, further deep studies for evaluation of the 
mechanism affected by the CcDof gene may help to devise new strategies and biotechnological applications for $C$. canephora plants.

\section{REFERENCES}

ALTSCHUL, S.F.; MADDEN, T.L.; SCHAFFER, A.A.; ZHANG, J.; ZHANG, Z.; MILLER, W.; LIPMAN, D. Gapped BLAST and PSIBLAST: a new generation of protein database search programs. Nucleic Acids Research, v.25, p.3389-3402, 1997. https://doi.org/10.1093/nar/25.17.3389

AZAM, S. M.; LIU, Y.; RAHMAN, Z. U.; ALI, H.; YAN, C.; WANG, L.; PRIYADARSHANI, S.V.G.N.; HU, B.; HUANG, X.; XIONG, J.; QIN, Y. Identification, Characterization and Expression Profiles of Dof Transcription Factors in Pineapple (Ananas comosus L.). Tropical Plant Biology, p. 1-16, 2018. https://doi.org/10.1007/s12042-018-9200-8.

CAI, X.; ZHANG, Y.; ZHANG, C.; ZHANG, T.; HU, T.; YE, J.; ZHANG, J.; WANG, T.; LI, H.; YE, Z. Genomewide analysis of plant-specific Dof transcription factor family in tomato. Journal of Integrative Plant Biology, v.55, n.6, p.552-566, 2013. https://doi.org/10.1111/jipb.12043.

CHEN, M.; LIU, X.; HUAN, L.; SUN, M.; LIU, L.; CHEN, X.; GAO, D.; LI, L. Genome-wide analysis of Dof family genes and their expression during bud dormancy in peach (Prunus persica). Scientia Horticulturae, v.214, p.18-26, 2017. https://doi.org/10.1016/j.scienta.2016.11.014.

CORRALES, A.R.; CARRILLO, L.; LASIERRA, P.; NEBAUER, S. G.; DOMÍNGUEZ-FIGUEROA, J.; RENAU-MORATA, B.; POLLMANN, S.; GRANELL, A.; MOLINA, R. V.; VICENTE-CARBAJOSA, J.; MEDINA, J. Multifaceted role of cycling Dof Factor 3 (CDF3) in the regulation of flowering time and abiotic stress responses in Arabidopsis. Plant Cell Environment, v.40, p.748-764, 2017. https://doi.org/10.1111/pce.12894.

DENOEUD, F.; CARRETERO-PAULET, L.; DEREEPER, A.; DROC, G.; GUYOT, R.; PIETRELLA, M.; ZHENG, C.; ALBERTI, A.; ANTHONY, F.; APREA, G. et al. The coffee genome provides insight into the convergent evolution of caffeine biosynthesis. Science, v.345, n.6201, p.1181-1184, 2014. https://doi.org/10.1126/science.1255274.

FENG, B.H.; HAN, Y.-C, XIAO, Y.-Y. ; KUANG, J.-F.; FAN, Z.-Q.; CHEN, J.-Y.; LU, WJ. The banana fruit
Dof transcription factor MaDof23 acts as a repressor and interacts with MaERF9 in regulating ripening-related genes. Journal of Experimental Botany, v. 67, p. 2263-2275, 2016. https://doi.org/10.1093/jxb/erw032.

GIBAS, C.; JAMBECK, P. Developing Bioinformatics Computer Skills. 1. ed. Lorrie Lejeune: O'Reilly Media, 2001 p. 446.

HU, BO.; JIN, J.; GUO, A-Y.; ZHANG, HE.; LUO, J.; GAO, G. GSDS 2.0: an upgraded gene feature visualization server. Bioinformatics, v.31, n.8, p.1296-1297, 2015. https://doi.org/10.1093/bioinformatics/btu817.

GUPTA, S.; ARYA, G. C.; MALVIYA, N.; BISHT, N.C.; YADAV, D. Molecular cloning and expression profiling of multiple Dof genes of Sorghum bicolor (L) Moench. Molecular Biology Reports, v.43, n.3, p.767-774, 2016. https://doi.org/10.1007/s11033-016-4019-6.

GUPTA, S.; MALVIYA, N.; KUSHWAHA, H.; NASIM, J.; BISHT, N. C.; SINGH, V. K.; YADAV, D. Insights into structural and functional diversity of Dof (DNA binding with one finger) transcription factor. Planta, v. 241, n. 3, p. 549-562, 2015. https://doi.org/10.1007/s00425-014-2239-3.

GUPTA, S.; PATHAK, R. K.; GUPTA, S. M.; GAUR, V. S.; SINGH, N. K.; KUMAR, A. Identification and molecular characterization of Dof transcription factor gene family preferentially expressed in developing spikes of Eleusine coracana L. 3 Biotech, v.8, n.2, p.82, 2018. https://doi.org/10.1007/s13205-017-1068-z.

HUANG, W.; HUANG, Y.; LI, M.Y.; WANG, F.; XU, Z.S.; XIONG, A.S. 2016. Dof transcriptionfactors in carrot: genome-wide analysis and their response to abiotic stress. Biotechnology Letters, v. 38, p. 145-155, 2016. https://doi.org/10.1007/s10529015-1966-2.

HOU, Y.; WU, A. L.; HE, Y. Y.; LI, F. D.; WEI, C. L. Genome-wide characterization of the basic leucine zipper transcription factors in Camellia sinensis. Tree Genetics \& Genomes, v. 14, p. 27, 2018. https://doi.org/10.1007/s11295- 018-12424.

ITO, T.M.; TREVIZAN, C.B.; DOS SANTOS, T.B.; DE SOUZA, S.G.H. Genome-Wide Identification and 
Characterization of the Dof Transcription Factor Gene Family in Phaseolus vulgaris L. American Journal of Plant Sciences, v. 8, p. 3233-3257, 2017. https://doi.org/10.4236/ajps.2017.812218.

JIN, Z.; CHANDRASEKARAN, U.; LIU, A. Genomewide analysis of the Dof transcription factors in castor bean (Ricinus communis L.). Genes Genomics, v.36, p.527-537, 2014. https://doi.org/10.1007/s13258-014-0189-6.

KANG, W.-H.; KIM, S.; LEE, H.-A.; CHOI, D; YEOM, S.-I. Genome-wide Analysis of Dof Transcription Factors Reveals Functional Characteristics during Development and Response to Biotic Stresses in Pepper. Scientific Reports, v.6, n.33332, 2016. https://doi.org/10.1038/srep33332.

KORALEWSKI, T.E.; KRUTOVSKY, K. V. Evolution of exon-intron structure and alternative splicing. PLoS One, v.6, e18055. 2011 https://doi.org/10.1371/journal.pone.0018055.

KREBS, J.; MUELLER-ROEBER, B.; RUZICIC, S. A novel bipartite nuclear localization signal with an atypically long linker in DOF transcription factors. Journal of Plant Physiology, v.167, n.7, p.583586 , 2010. https://doi.org/10.1016/j.jplph.2009.11.016.

KUSHWAHA, H.; GUPTA, S.; SINGH, V.K.; RASTOGI, S.; YADAV, D. Genome wide identification of Dof transcription factor gene family in sorghum and its comparative phylogenetic analysis with rice and Arabidopsis. Molecular Biology Reports, v. 38, p. 5037-5053, 2011. https://doi.org/10.1007/s11033-010-06509.

LI, DH.; LIU, P.; YU, J. Y.; WANG, L. H.; DOSSA, K.; ZHANG. Y. X.; ZHOU, R.; WEI, X.; ZHANG, X. R. Genome-wide analysis of WRKY gene family in the sesame genome and identification of the WRKY genes involved in responses to abiotic stresses. BMC Plant Biology v. 17, n. 1, p. 152, 2017. https://doi.org/10.1186/s12870-017-1099y.

LIJAVETZKY, D.; CARBONERO, P.; VICENTECARBAJOSA, J. Genome-wide comparative phylogenetic analysis of the rice and Arabidopsis Dof gene families. BMC Evolutionary Bioogy. v. 3, n.17, 2003. https://doi.org/10.1186/1471-21483-17.
MA, J.; LI, M-Y.; WANG, F.; TANG, J.; XIONG, A. S. Genome-wide analysis of Dof family transcription factors and their responses to abiotic stresses in Chinese cabbage. BMC Genomics v. 16, p. 33, 2015. https://doi.org/10.1186/s12864-015-12429.

MALVIYA, N.; GUPTA, S.; SINGH, V.K.; YADAV, M.K.; BISHT, N.C.; SARANGI, B.K.; YADAV, D. Genome wide in silico characterization of Dof gene families of pigeonpea (Cajanus cajan (L) Millsp.). Molecular Biology Reports, v. 42, n. 2, p. 535-552, 2015. https://doi.org/10.1007/s11033014-3797-y.

MORENO-RISUENO, M.Á.; DÍAZ, I.; CARRILLO, L.; FUENTES, R.; CARBONERO, P. The HVDOF19 transcription factor mediates the abscisic aciddependent repression of hydrolase genes in germinating barley aleurone. Plant Journal, v. 51, p.352-365, 2007. https://doi.org/10.1111/i.1365313X.2007.03146.x.

PROSDOCIMI, F.; CERQUEIRA G. C.; BINNECK, E.; SILVA, A. F.; NEVES, A. ET AL. Bioinformática: manual do usuário. Biotecnologia Ciência \& Desenvolvimento, v. 29, p. 12-25, 2002.

ROY, S.W.; GILBERT, W. The evolution of spliceosomal introns: patterns, puzzles and progress. Nature Reviews Genetics, v. 7, p. 211221, 2006. https://doi.org/10.1038/nrg1807.

SHU, Y.J.; SONG, L.L.; ZHANG, J.; LIU, Y.; GUO, C. $\mathrm{H}$. Genome-wide identification and characterization of the Dof gene family in Medicago truncatula. Genetics and Molecular Research, v.14, n.3, p.10645-10657, 2015. https://doi.org/10.4238/2015.September.9.5.

SILVA, D.C.; FALAVIGNA, V.S.; FASOLI, M.; BUFFON, V.; PORTO, D.D.; PAPPAS JR, G.J.; PEZZOTTI, M.; PASQUALI, G.; REVERS, L.F. Transcriptome Analyses of the Dof-Like Gene Family in Grapevine Reveal Its Involvement in Berry, Flower and Seed Development. Horticulture Research, v.3, n.16042, 2016. https://doi.org/10.1038/hortres.2016.422.

SONG, A.; GAO, T.; LI, P.; CHEN, S., WU, D.; XIN, J.; FAN, Q.; ZHAO, K.; CHEN, F. Transcriptome-Wide Identification and Expression Profiling of the DOF Transcription Factor Gene Family in Chrysanthemum morifolium. Frontiers in Plant 
$\begin{array}{llll}\text { Science } & \text { v.7, } & \text { n.199, } & \end{array}$ https://doi.org/10.3389/fpls.2016.00199.

VENKATESH, J.; PARK, S.W. Genome-wide analysis and expression profiling of DNA-binding with one zinc finger (Dof) transcription factor family in potato. Plant Physiology and Biochemistry, v.94, p.73-85, 2015. https://doi.org/10.1016/j.plaphy.2015.05.010.

VOORRIPS, R.E. MapChart: Software for the Graphical Presentation of Linkage Maps and QTLs. Journal of Heredity, v.93, p.77-78, 2002. https://doi.org/10.1093/jhered/93.1.77

WANG, T.; YUE, J.-J.; WANG, X.-J.; XU, L.; LI, L.-B.; $\mathrm{GU}, \quad X .-P$. Genome-Wide Identification and Characterization of the Dof Gene Family in Moso Bamboo (Phyllostachys heterocycla var. pubescens). Genes \& Genomics, v.38, n.733, 2016. https://doi.org/10.1007/s13258-016-04182.

WANG, P.; LI, J.; GAO, X.; ZHANG, D.; LI, A.; LIU, C. Genome-Wide Screening and Characterization of the Dof Gene Family in Physic Nut (Jatropha curcas L.). International Journal of Molecular sciences, v.19, n.6, p.1598, 2018. https://doi.org/10.3390/ijms19061598

WEI, Q.; WANG, W.; HU, T.; HU, H.; MAO, W.; ZHU, Q.; BAO, C. Genome-wide identification and characterization of Dof transcription factors in eggplant (Solanum melongena L.). PeerJ, $\mathrm{n}$. $6 \mathrm{e} 4481$, 2018.

https://doi.org/10.7717/peerj.4481/supp-1.

WEN, C. L.; CHENG, Q.; ZHAO, L.; MAO, A.; YANG, J.; YU, S.; WENG, Y.; $X U$, Y. Identification and characterisation of Dof transcription factors in the cucumber genome. Scientific Reports, v. 6, n.23072, 2016. https://doi.org/10.1038/srep23072.

WU, Z.; CHENG, J.; CUI, J.; XU, X.; LIANG, G.; LUO, X.; CHEN, X.; TANG, X.; HU, K.; QIN, C. Genomewide identification and expression profile of dof transcription factor gene family in pepper (Capsicum annuum L.). Frontiers in Plant Science, v.7, n.574, 2016. https://doi.org/10.3389/fpls.2016.00574.

XU, X.; LI, F.; WANG, Y.; TANG, S.; DAI, Q.; ZHU, S.; LIU, T. Identification of Dof transcription factors in ramie (Boehmeria nivea L. Gaud) and their expression in response to different nitrogen treatments. 3 Biotechonoly, v. 8, n. 12, p. 496, 2018 https://doi.org/10.1007/s13205-0181512-8.

YANAGISAWA S. A novel DNA-binding domain that may form a single zinc finger motif. Nucleic Acids Research v. 23, p. 3403-3410, 1995 https://doi.org/10.1093/nar/23.17.3403.

YANAGISAWA S. Dof DNA-binding domains of plant transcription factors contribute to multiple protein-protein interactions. European Journal of Biochemistry, v. 250, p. 403-410, 1997. https://doi.org/10.1111/j.14321033.1997.0403a.x.

YANAGISAWA, S.; SHEEN J. Involvement of maize Dof zinc finger proteins in tissue specific and light-regulated gene expression. The Plant Cell v.10, n.1, p.75-89, 1998. https://doi.org/10.1105/tpc.10.1.75

YANG, Q.; CHEN, Q.; ZHU, Y.; LI, T. Identification of MdDof genes in apple and analysis of their response to biotic or abiotic stress. Functional Plant Biology, v. 45, n. 5, p. 528-541, 2018. https://doi.org/10.1071/FP17288.

ZHANG, L.; LIU, B.; ZHENG, G.; ZHANG, A.; LI, R. Genome-wide characterization of the SiDof gene family in foxtail millet (Setaria italica). Biosystems, v. 151, p. 27-33, 2017 a. https://doi.org/10.1016/j.biosystems.2016.11.00 7.

ZHANG, Z.; YUAN, L.; LIU, X.; CHEN, X.; WANG, X. Evolution analysis of Dof transcription factor family and their expression in response to multiple abiotic stresses in Malus domestica. Gene, v.639, p.137-148, 2017b. https://doi.org/10.1016/i.gene.2017.09.039.

ZHANG, C.; MA, R.; XU, J.; YAN, J.; GUO, L.; SONG, J.; FENG, R.; YU, M. Genome-wide identification and classification of MYB superfamily genes in peach. PLoS One n. 13:e0199192, 2018. https://doi.org/10.1371/journal.pone.0199192. 
Recebido para publicação em 17/12/2018

Revisado em 14/02/2019

Aceito em 14/02/2019 